\title{
Vesoul 2013
}

\author{
By Gönül Dönmez-Colin
}

Spring 2014 Issue of KINEMA

\section{$20^{\text {th }}$ VESOUL INTERNATIONAL FILM FESTIVAL OF ASIAN CINEMA (11-18 February 2014)}

Vesoul International Film Festival of Asian Cinema is a rare event not only in its program dedicated solely to the cinemas of Asia, but also in the manner it is run, which is an important factor in drawing film-lovers from all over the world every year to a rather ordinary town in the middle of winter. A family affair, with Martine and Jean-Marc Thérouanne at the helm, the opening night commenced with a cocktail in their house, followed by a ceremony at the largest theatre in town. For the $20^{\text {th }}$ anniversary, the concert from Vietnam, the traditional dance show from the Philippines and a Jô-do martial art performance from Japan were followed by an inspiring film on the twenty years of the festival that started with one small theatre for projection and an adjacent tent for meetings, with Mr Thérouanne collecting tickets at the door. Thanks to the remarkable success of the festival over the years and the construction of a multiplex near by, the festival now uses five cinema halls on the weekends and three on the week-days.

The jury, presided by the remarkable filmmaker from the Philippines, Brillante Mendoza, included the young Iranian actor, Taraneh Alidoosti who is most remembered for Rasul Sadr Ameli's film, I am Tareneh, 15 (2002) and three films of Asghar Farhadi, including About Elly (2009); the ex-director of the Singapore International Film Festival, Philip Cheah and Joceyln Saab, the distinguished Lebanese filmmaker. Nine films having their French premiere competed for the Golden Cyclo. The Ferry by Shi Wei (China, 2013), a humanist story about dying rural customs; 10 Minutes by Lee Yong-seung (South Korea, 2013) about the limited work opportunities available to young people in modern Korea; Quick Change (Eduardo Roy Jr., 2013), a highly entertaining film from the Philippines about transsexuals and the trafficking of illegal cosmetics; Köksüz (Nobody's Home, 2013) by Deniz Akçay from Turkey about a dysfunctional family; Barf Roye Kajha (The Snow on the Pines, 2013) by Peyman Moaadi from Iran with the remarkable cinematography of Mahmoud Kalari and a psychological drama from Japan involving two adolescents, Yurusenai Aitai (Again, 2013) by Kanai Junichi were some of the highlights.

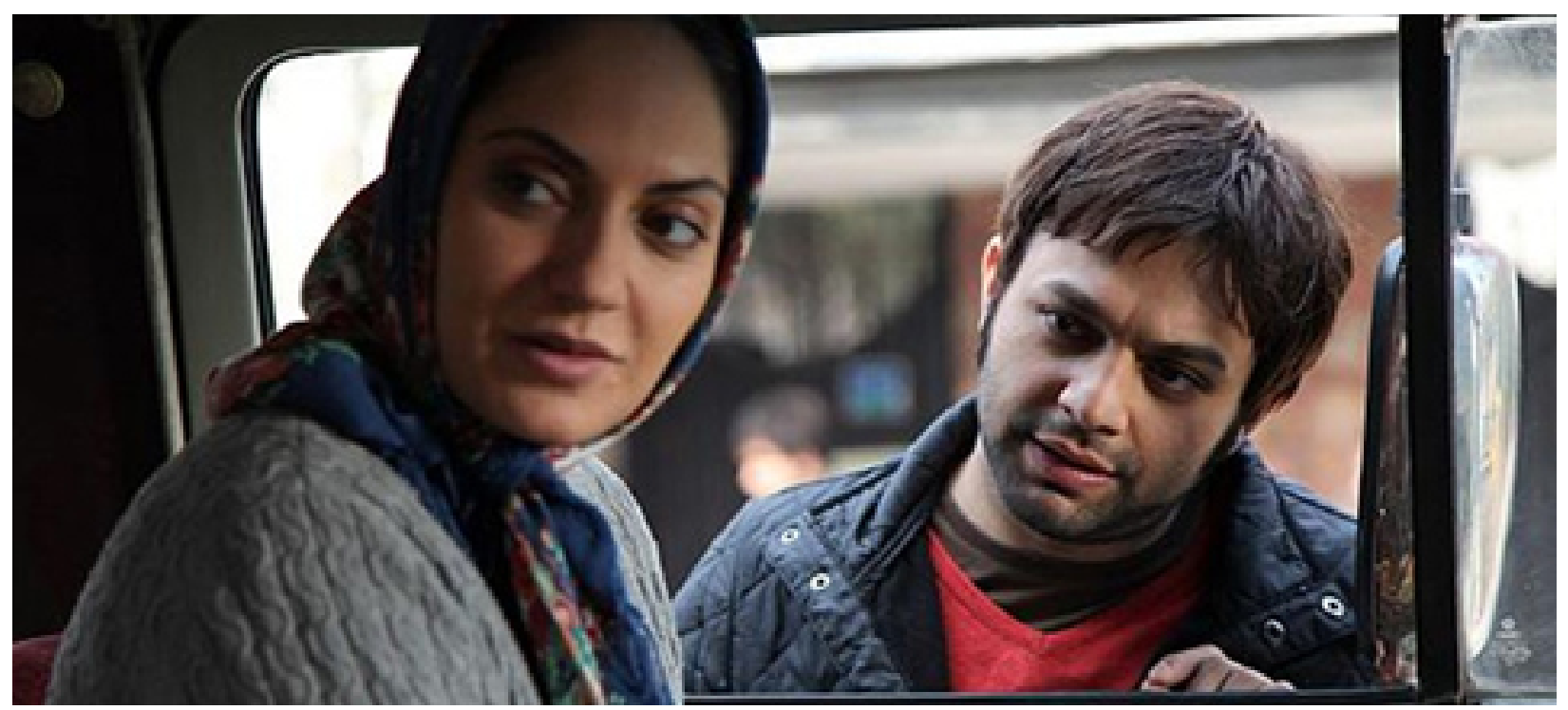

Figure 1: The Snow on the Pines by Peyman Moaadi

One of the most talked about films from the competition was Tanzania-born Anup Singh's Qissa (India, 2013). Sumptuously photographed, impressively acted by Irfan Khan (Life of Pi, The Lunch Box) with 
ample diegetic and non-diegetic song and dance in the traditional style of Indian cinema, the film narrates the story of a young Sikh who leaves Pakistan after the partition in 1947 and settles in the Punjab region of India. After three girls, when his wife gives birth to a fourth, he concocts a scheme to hide the fact and pretend the baby is a boy. All is well until she grows up. A gypsy girl is tricked into marrying her but no gold in the world would make her accept impregnation by her father-in-law. The two girls become fugitives. At this point the film somewhat loses its tempo as it shies away from exploring the deeper angles of their characters and their relationship, which could have given another dimension to the film.

'A look at the 20 Years of Vesoul' brought back some gems that one does not tire to see over and over again such as Apur Sansar (The World of Apu, Satyajit Ray, India, 1959) and Kizzu ritân (Kid's Return, Kitano Takeshi, Japan, 1996). One film that I had the chance to see again was Seishun zankoku monogatari (Cruel Tales of Youth, Oshima Nagasi, Japan, 1960), a landmark film of Japanese cinema that has not lost its contemporaneity. The 'Carte Blanche of Our Twenty Years' brought to Vesoul Ukigumo (Floating Clouds, Naruse Mikio, Japan, 1955) and Chung hing sam lam (Chungking Express, Wong Kar-Wai, 1994) among other remarkable works.

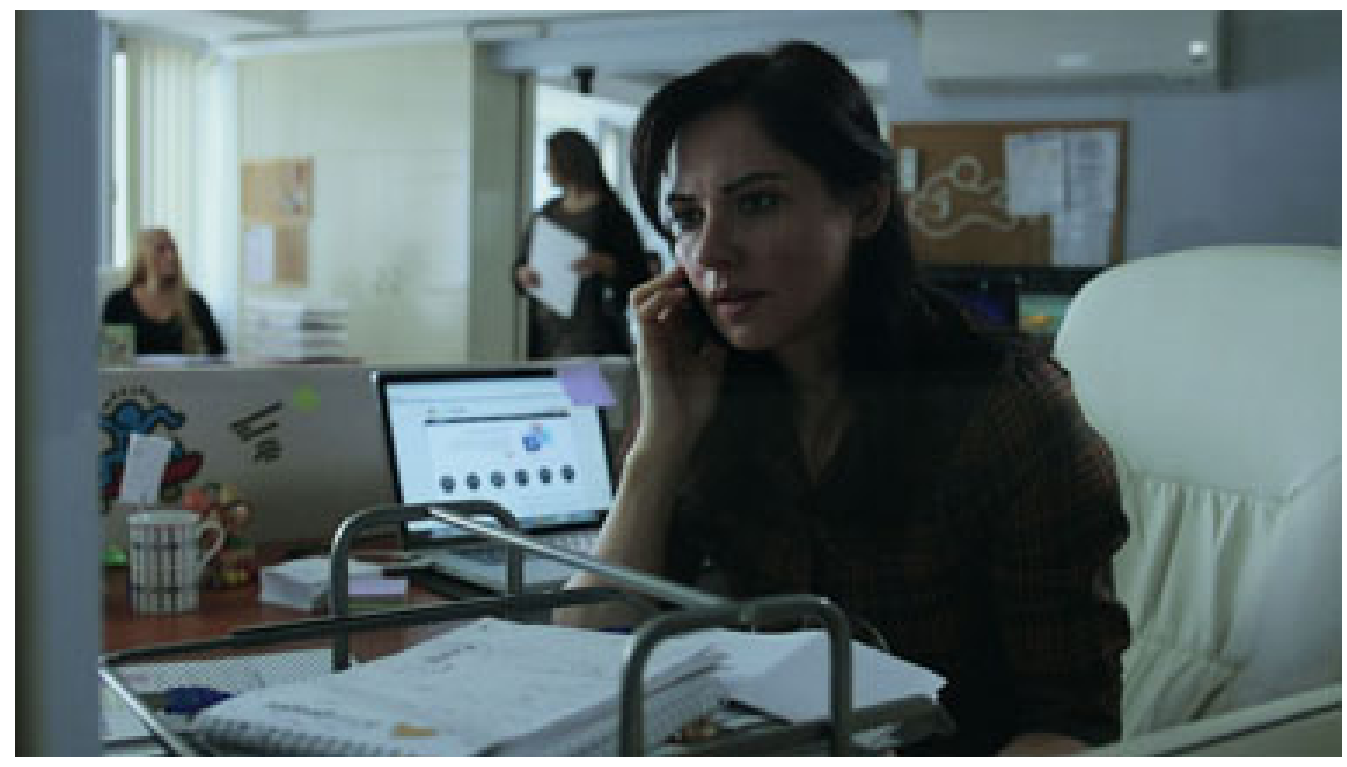

Figure 2: Nobody's Home by Deniz Akçay

A real treat was the section on the cinema of the Philippines: 'From Oblivion to a New Release of Life.' Mendoza's John John (Foster Child, 2007), Lola (2009), Sinapupunan (Thy Womb, 2012) and Captive (2012) are films worth multiple viewings. His latest Sapi (2013), about the media and the ratings wars that ignore human values, is a strong commentary on our modern world, with exceptional camera angles and an original film language.

The voyage down the memory lane of the Philippine cinema included Lino Brocka's classic, Maynila sa mga Kuko ng Liwanag (Manila In the Claws of the Neon, 1975) restored recently by the World Cinema Foundation and Ganito kami noon, paano kayo ngayon? (This is How We Live, 1976) by Eddie Romero, a historical piece rich with humor questioning Philippino identity through the adventures of a young, naive and innocent hero - a metonym for the nation who learns the hard way, or never does. Some of the classics by Ishmael Bernal, Marilou Diaz-Abaya and Ditsi Carolino were also included in this section. A pleasant surprise was presented through a film by Marlon Rivera, which casts a critical eye on the independent Philippine cinema, Mendoza included. Ang babae sa septic tank (The Woman in the Septic Tank, 2011), with remarkable acting by the glorious Eugene Domingo acting herself, focuses on a group of filmmakers ready to shoot a film in the slums of Manila. Dreaming of Oscars, they charm Domingo into accepting the lead role of a woman who tries to sell one of her seven hungry children to an old European man (echoes of Mendoza's Foster Child).

'Vietnamese Cinema Since Re-unification' was another remarkable section that visited some of the classics 


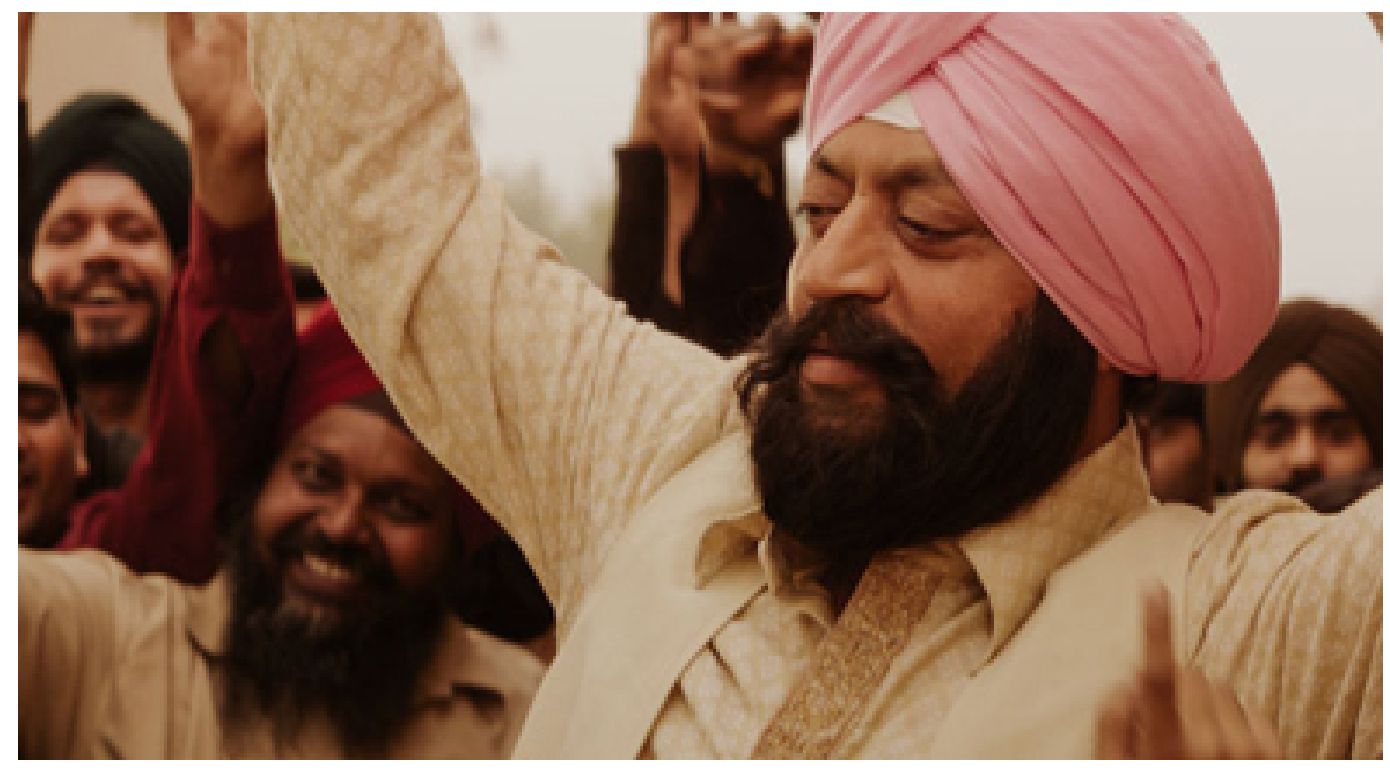

Figure 3: Quissa by Anup Singh

such as Bao gio cho den thang muoi (When the Tenth Month Comes, 1984) by Dang Nhât Minh, the great master who was present.

The Young Public section, followed closely by the high-school students in the area, the documentaries and the Japanimation were the other alluring sections of the festival that screened a total of 100 films, if one could have the time to see them all. The film posters and the photography exhibition of the filmmaker Jérome Bouyer about the Philippines were the bonus events in addition to thematic cultural evenings.

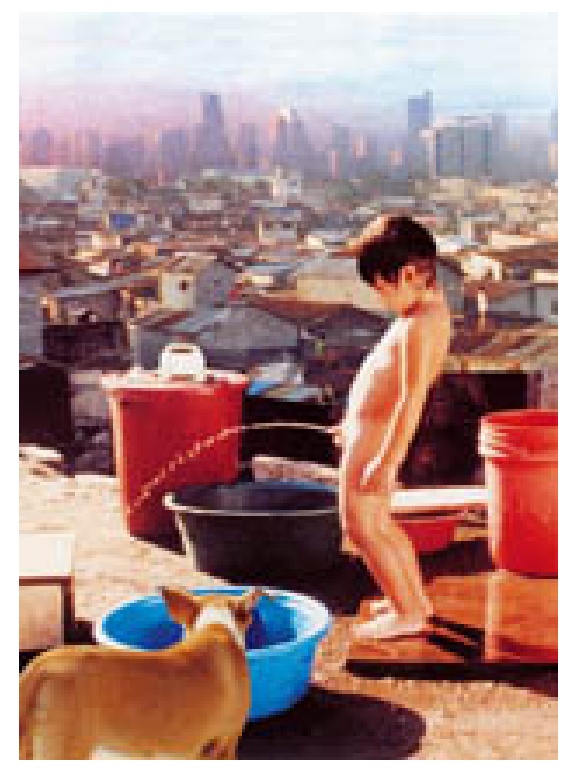

Figure 4: Foster Child by Brillante Mendoza

During the closing ceremony, Brillante Mendoza was honoured with a Golden Cyclo, followed by the screening of his film, Foster Child. For the lovers of Asian cinema - academic, critic or laymen - Vesoul is the best place to be. With excellent management that relies mostly on volunteers, the special programs on chosen countries are always meticulously prepared - like a wonderful lesson in cinema if not a beautiful dream of travelling 
around the world without leaving your seat. Therein lies the secret of reaching over 30,000 admission figures in a town of 15,600 population.

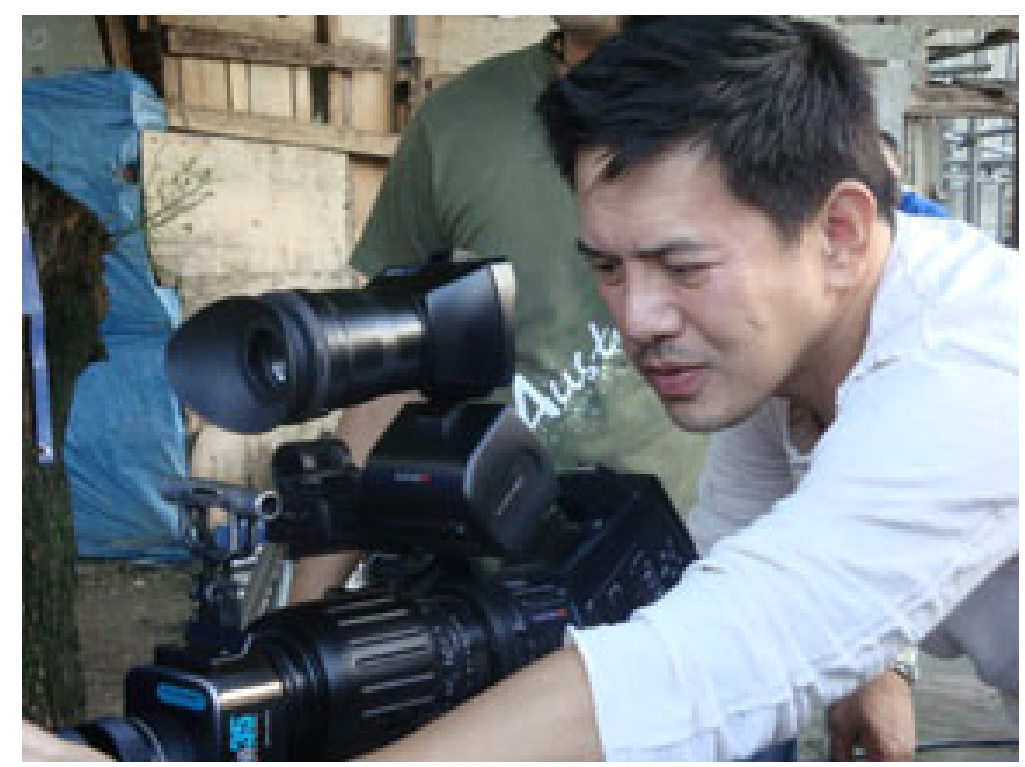

Figure 5: Philippine Director Brillante Mendoza

\section{References}

\section{Awards}

Golden Cyclo: 10 Minutes by Lee Yong-seung (South Korea)

Grand Jury Prize: Nobody's Home by Deniz Akçay (Turkey)

Jury's Special Mention: Quissa by Anup Singh (India)

Netpac Award (Network for the Promotion of Asian Cinema): The Ferry by Shi Wei (China)

Émile Guimet Award (granted by The Friends of National Museum of Asian Arts of Paris): The Ferry by Shi Wei (China)

Inalco Jury Award (granted by The National Institute of Oriental Languages and Civilizations, Paris): Quissa by Anup Singh (India)

Inalco's Special Mention: 10 Minutes by Lee Yong-seung (South Korea)

Critics Jury's Prize: Quick Change by Eduardo Roy Jr. (Philippines)

Audience Award For A Fiction Film (granted by The City of Vesoul): Again by Kanai Junichi (Japan)

High Schools Award: Nobody's Home by Deniz Akçay (Turkey)

Audience Award For Documentary Films (granted by The Communauté d'agglomération de Vesoul): Mille Jours A Saigon (1000 Days in Saigon) by M.C. Courtès (Vietnam - France)

Youth Award (granted by The Communauté d'agglomération de Vesoul): Blossom With Tears by Jin Huaqing (China). 


\section{Author Information}

Gönül DÖNMEZ-COLIN is an independent researcher and writer whose publications include Women, Islam and Cinema, Cinemas of the Other: A personal Journey with Filmmakers from the Middle East and Central Asia, Cinema of North Africa and the Middle East (ed.); Turkish Cinema: Identity, Distance and Belonging (Reaktion Books), and Routledge Dictionary of Turkish Cinema (2014). 